\title{
ANALYSIS OF EMPLOYEE INVOLVEMENT IN ONLINE OJEK DRIVERS IN BATAM CITY
}

\author{
Antony $\mathrm{S}^{1)}$, Yuli Indah Fajar Dini ${ }^{2)}$ \\ ${ }^{1,2)}$ Universitas Internasional Batam \\ Corresponding author: antony.sentoso@yahoo.com,yuli.indah@yahoo.co.id
}

\begin{abstract}
The number of internet users in Indonesia has already reached 64\% of Indonesia's total, more than 175.4 million. Furthermore, in April 2020, the total number of ojek online drivers in Indonesia is 4 million drivers. It becomes interesting to study employee engagement on ojek online drivers because of their partnership with the online transportation company that owns the application. The ojek online drivers who also free to decide their operational hours and join more than one application. Respondents have taken the employee engagement study obtained by random sampling conducted to Ojek online drivers who operated in Batam City. The writer distributed hard copies of 300 questionnaires straight to the drivers who operated in the fields and distributed them online using Google Form through the WhatsApp application. After doing the verification and outlier test to 417 respondent data, only 351 data were left for further analysis using SPSS (Statistical Package for Social Science) version 24. The research results described that reward and recognition, employee empowerment, and leadership significantly influence the employee engagement of ojek online drivers to the owner of online transportation applications.
\end{abstract}

Keywords: Employee Engagement, Reward and Recognition, Employee Empowerment, Leadership

\section{Introduction}

PT Aplikasi Karya Anak Bangsa, better known as Gojek, was founded in Jakarta by Nadiem Makarim in 2010. Gojek operated only with 20 motorcycle taxi drivers and still used the communication system through operators as written by (Yusuf 2019) via https://tekno.kompas.com. The establishment of Gojek in 2010, and followed by the Grab in Jakarta in 2014. Grab is one of the online transportation companies from Malaysia. Based on data from https://www.liputan6.com written by (Cahyu 2019), Grab was founded in Malaysia in 2012 by Anthony Tan and Hooi Ling Tan.

With Grab's entry into Indonesia and Uber's increasing popularity at that time, in 2015 , Gojek launched its Android and IOS-based application. Furthermore, up to now, the Gojek application already has 28 services. The Gojek application services are quite a lot compared to the services on the Grab application, which only amount to 10 services. Gojek is already operating in 167 cities and regencies throughout Indonesia. Unlike Gojek, Grab's operational area is much larger and broader, covering 222 locations throughout Indonesia as published (Grab, 2020) through its website at https://www.grab.com.

Batam City is one of the cities that is the operational area of Gojek and Grab. Starting with Gojek, which entered Batam City in 2016, Grab and Maxim followed. Maxim, an online transportation company from Russia, has also been operating in Batam City starting February 2019 as stated by (Ikhsan 2019) via https://www.batamnews.id.

The number of services available on the Gojek, Grab, and Maxim applications, of course, increases the opportunities for online motorcycle taxi driver-partners to earn more apart from running the ojek transportation service itself. Services that provide much income for drivers are purchasing food and beverages and delivering goods. This condition certainly creates an attachment between online motorcycle taxi drivers and the company. Even though the relationship between online motorcycle taxi drivers and the application owner company is a partnership relationship, that owns the application. This partnership online motorcycle taxi drivers are free to determine their operational time and are not limited to being tied to only one application.

Therefore, the authors are interested in analyzing the employee engagement of online motorcycle taxi drivers in the city of Batam towards the company. The number of online motorcycle taxi drivers in Indonesia is estimated to have reached four million drivers in April 2020, as conveyed by the Chairperson of the Indonesian National Guard, Igun Wicaksono, through https://kumparan.com written by (Kumparan, 2020).

Employee involvement is a form of relationship in terms of performance that binds both cognitively, physically, and emotionally between a member of an organization and the organization supporting it (Kahn, 1990). Employee involvement is the readiness of an employee and all his / her abilities to make the best contribution to a company's success, which is carried out continuously. This is strongly influenced not only by emotional factors but also by the ratio of thinking factors relating to the job itself and his experience working as a whole (Perrin, 2003).

Employee involvement is an employee's attitude that positively responds to the company or organization that houses it and its values. What needs to be considered to increase employee involvement is a sense of being respected and involved in various company activities, including being able to express opinions in 
decision making, the opportunity to be able to get a better position, and a form of concern from the company for the welfare and health conditions of its employees (Robinson et al., 2004).

Employee engagement is the result of a combination of behavior, personality, abilities

in work, the knowledge and expertise possessed by an employee with matters relating to the company, namely leadership patterns, workplace arrangements both socially and physically, the application of HRM (Human Resource Management) to employees, the processes being carried out, and related matters with performance (Vance, 2004).

Employee involvement is a positive thing that a worker owns related to his attitude towards an organization and the values of the organization that supports it, where a worker can work well together to boost the predetermined achievements of a work unit organization through well-established cooperation between the workers and the management of the organization (Robinson et al., 2004).

Employee involvement is a positive mindset that can be used to accomplish everything related to work, described as enthusiasm, dedication, and absorption (Schaufeli \& Bakker, 2004).

Employees will have three general behaviors: Say, Stay and Strive, which are essential to improve company performance if the worker has a sense of involvement with the company that supports them (Baumruk, R., Gorman, Jr., B., \& Gorman, 2006).

Employee involvement is something that connects a high intellectual and emotional condition between a worker and what he does, his organization, his boss, his leader, or fellow workers, which can have a positive impact in order to increase discretionary effort in the work he does ( Hughes \& Rog, 2008).

Employee engagement is an Organizational Citizenship Behavior (OCB) technique that has been developed so that it can give management a more in-depth view that employee engagement with the company is an essential factor that must be considered in order for the level of productivity and work efficiency as desired. . Because no matter how good the development initiatives that are raised will not be able to provide relevant results if it is not followed by the participation and commitment of employees (Markos \& Sridevi, 2010).

Employee involvement is a shared commitment between the company and employees. The incentive/reward given can lead to a loss of employee motivation if the giving does not pay attention to autonomy, expertise, and goals. The existence of incentives/rewards will harm the company if it is not appropriately controlled. This also applies to employees, even though they already have a large salary. If the worker does not feel involved in the organization, the worker will lose his motivation to work, as Pink (2009) stated (Spawr, 2012).

Employee involvement can also be interpreted as how to encourage a worker to achieve the highest performance so that they can make the best contribution to the company. From an employee's perspective, a personal relationship with a direct supervisor is a key where the attitude showed and the actions. The supervisor can increase the level of employee involvement in an employee or otherwise create a condition that makes the employee no longer able to feel an essential part of an employee. Company/organization or feel disengaged. For an employee, a senior's ability to lead, receive input, provide the right direction for the company, and communicate about its condition are things that need to be considered to bind employees. If a company can appreciate and treat its employees well, it will generate involvement in its employees.

Another term that often appears in discussions about employee engagement is work engagement. Job involvement increases job satisfaction, reduces psychological tension, and improves performance (Gaëtane Caesens, 2014). Based on the definition of job involvement above, employee involvement and job involvement have the same meaning.

A hypothesis is an essential scientific research tool that aims to help researchers carry out a process of analysis that combines two or more variables. The study was conducted to formulate three hypotheses to be tested for the independent variable's influence on the dependent variable, and the researcher proposes the following hypothesis.

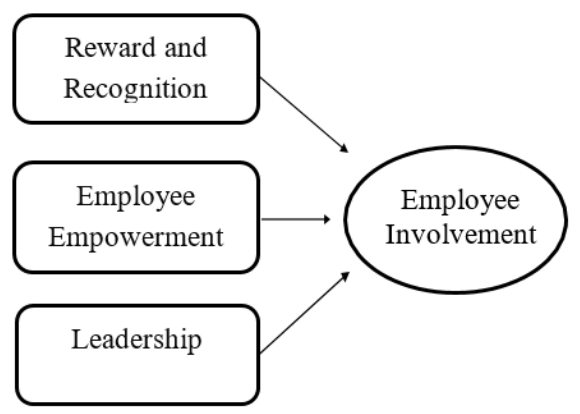

Figure 1. Conceptual Framework

H1: There is a significant positive effect between Reward and Recognition to Employee Involvement. H2: There is a significant positive effect between Employee Empowerment to Employee Involvement. H3: There is a significant positive effect between Leadership to Employee Involvement. 


\section{Research Method}

At the time of conducting this research, the author aims to determine the involvement of employees in online motorcycle taxi drivers in the city of Batam towards the companies that own the online transportation applications they use. Given the working relationship between online motorcycle taxi drivers and the company that owns the application is a partnership. Furthermore, as partners, online motorcycle taxi drivers have no connection with the company that owns the online transportation application. Online motorcycle taxi drivers are free to determine working hours and working days according to their respective wants and needs.

Based on the nature of the research, the authors conducted quantitative research. According to (Sujarweni, 2014) quantitative research is one type of research that produces discoveries that can be achieved (obtained) by using statistical procedures or other means of quantification (measurement). A quantitative approach focuses on the symptoms that have specific characteristics in human life, called variables. In a quantitative approach, the nature of the relationship between variables is analyzed using an objective theory. Kasiram (2008) in (Sujarweni 2014) defines quantitative research as a process to find the knowledge that uses data in the form of numbers as a tool to analyze information about what you want to know.

In this study, the authors used quantitative descriptive and survey methods. In quantitative research, the survey is one of the research methods intended to obtain information about the characteristics, actions, and opinions representing the population through a questionnaire or interview where the researcher does not attempt to treat the research process variables specifically. Using the survey method in this study, the author can get a more transparent and more detailed picture of something general in nature (Adiyanta, 2019). Quantitative descriptive is one type of research that is useful for providing descriptions or descriptions of numbers that have been processed according to specific standards.

The population that will be used as the object of research by the authors in this study are online motorcycle taxi drivers operating in Batam. Meanwhile, the sample used in this study is online motorcycle taxi drivers who use online transportation applications such as Gojek, Grab, and Maxim. For the sampling method, the authors did it randomly. The author uses a random sampling method because every online motorcycle taxi driver who uses the Gojek, Grab, and Maxim applications have an equal position. Thus, every online motorcycle taxi driver operating in Batam and using the Gojek, Grab, and Maxim applications have the same opportunity to be used as samples in this study.

The sample used by the author is obtained from 365 data respondents. To determine the number of samples used in this study, the authors used references from nine journals. Data in nine journals shows that the average sample used is 232 respondent data, a minimum of 137 respondent data, and 334 respondent data. The following is the number of samples used by each journal that the author uses as a reference. Kaliannan and Adjovu (2015) used 137 samples; Raziq and Maulabakhsh (2015) used 210 samples; Taufek, Zulkifle, and Sharif (2016) used 250 samples; Vallières et al. (2017) used 334 samples; Sharma, Goel, and Sengupta (2017) used 303 samples; Pan et al., (2017) used 161 samples; Hanaysha (2016) used 242 samples; and Maciel and Camargo (2016) using 249 samples.

\section{Result and Discussions}

Based on the results of the analysis, several statements were declared invalid. The value of the loading factor determines the validity or invalidity of a statement. The magnitude of this loading factor value shows the strength of the closeness of the relationship or association of each statement with its variables. A statement is declared valid if the loading factor value is $>0.6$ (Ghozali, 2011; Hair et al., 2009). So that statements that have a loading factor value $<0.6$ are declared invalid.

Results reveal that there are several statements used by the authors in the questionnaire which are declared invalid. For the independent variable of appreciation and recognition, which consists of five statements, all the authors' statements in the questionnaire are declared valid because they have a loading factor value of $>0.6$. The loading factor value of each of these statements is 0.644 for the statement of appreciation and recognition 1; 0.871 for the statement of appreciation and recognition 2; 0.868 for the statement of appreciation and recognition 3; 0.900 for the statement of appreciation and recognition 4 and 0.857 for the statement of appreciation and recognition 5 .

In the leadership independent variable with five statements, one statement has a loading factor of 0.488 , namely the leadership statement 1 , so it is declared invalid. Meanwhile, the other four statements are included in the excellent category because they have a loading factor value of 0.815 for leadership statements 2, 0.828 for the leadership statement 3, 0.805 for the leadership statement 4, and 0.837 statements 5 .

Then for the independent variable, employee empowerment, which has eight statements, the employee empowerment statement 1 and the employee empowerment statement 3 have a loading factor of 0.469 and 0.440 , so that it is declared invalid. At the same time, the other six statements have a loading factor greater than 0.6 , namely 0.644 for statements of employee empowerment 2;0.808 for employee empowerment statements $4 ; 0.797$ for the statement of employee empowerment $5 ; 0.702$ for the employee empowerment statement 6; 0.808 for statements of employee empowerment 7 and 0.827 for statements of employee empowerment eight so that the six statements about the empowerment of other employees were declared valid. 
For the dependent variable employee involvement using nine statements in the questionnaire, one statement is declared invalid. This statement is a statement on employee involvement nine, which has a loading factor value of 0.572. Meanwhile, eight other employee involvement statements were declared valid with the loading factor values as follows: 0.745 for statements of employee involvement $1 ; 0.782$ for employee engagement statements 2; 0.772 for employee engagement statements 3;0.721 for employee engagement statements 4;0.671 for the employee engagement statement 5, 0.725 for the employee engagement statement 6; 0.720 for the employee engagement statement 7 and 0.663 for the employee engagement statement 8 .

The next quantitative test performed by the author using SPSS version 24 software is the reliability test. The reliability test was carried out on the dependent variable and the independent variable used in the study. Based on the analysis results, the Cronbach's Alpha value of each of the independent variables and the dependent variable used in this study has a value greater than 0.6. Hair et al. (2011) stated that a variable would be declared reliable if it has a Cronbach's Alpha value greater than or equal to 0.6. Here, the one with the most significant Cronbach's Alpha value is the reward and recognition variable with a value of 0.887 . He was then followed by the employee engagement variable with a Cronbach's Alpha value of 0.873. Next is the employee empowerment variable with a Cronbach's Alpha value of 0.870 and finally, the leadership variable with a Cronbach's Alpha value of 0.822 .

The next test conducted by the author in this study is the multicollinearity test. This multicollinearity test is carried out on the independent variable and the dependent variable that the writer uses in this study. The multicollinearity test results have been carried out by the author using SPSS version 24 software. The result shows the numbers that are the parameters of this test result. The value in the VIF column or Variance Inflation Factors is something that must be considered. The value of VIF or Variance Inflation Factors for each of the independent variables of appreciation and recognition, leadership, and employee empowerment has a value of less than 10. Namely, 1.550 for the reward and recognition variables, 2.361 for the leadership variable, and 2.603 for the employee empowerment variable. Based on the results of the multicollinearity test shown by the VIF value or Variance Inflation Factors, it can be concluded that the variables used by the author in this study do not exist or do not find multicollinearity.

Another test carried out by the author in this study was the heteroscedasticity test, carried out using SPSS version 24 software. Based on the results of the analysis presented in Figure 2 above, it can be seen that the distribution of points in the scatter plot is at the top of the zero. The distribution below zero does not look like spreading, narrowing, depicting a specific pattern, or forming a line. Linear. So based on the results of the scatter plot above, it can be concluded that there is no heteroscedasticity found so that the homoscedasticity assumption for the research conducted by the author is related to the independent variables that affect the involvement of employees of online motorcycle taxi drivers in the city of Batam.

Hypothesis testing conducted by the author using SPSS version 24 software, among others, is the F test. This test was carried out to determine whether the independent variables used in this study, namely appreciation and recognition, leadership, and employee empowerment, could affect together or simultaneous to the dependent variable, in this case, employee involvement.

Based on the analysis results, it is revealed that the level of significance of the relationship between the independent variables consisting of appreciation and recognition, employee empowerment, and leadership with the dependent variable employee involvement is 0.000 or less than 0.05 . So from this level of significance, appreciation, and recognition, leadership and employee empowerment simultaneously and significantly affect employee engagement. This study's results are in line with the results of research by Osborne and Hammoud (2017). Based on the test results above, the independent variables consisting of appreciation and recognition, leadership and empowerment of employees together or simultaneously can have a significant positive effect on employee involvement of online motorcycle taxi driver-partners in the city of Batam to the company that owns the application it uses.

After seeing the $\mathrm{F}$ test results previously submitted to determine whether the independent variables simultaneously or together have a significant positive effect on the dependent variable, the authors also test the next hypothesis. This test is the t-test. The author's t-test aims to determine whether the authors' independent variables in this study can have a significant positive effect on the dependent variable, in this case, employee involvement partially or separately.

Based on the results of the analysis, it is revealed that the significance level of the relationship between reward and recognition of employee involvement is $0.000(<0.05)$. Therefore, it can be concluded that there is a significant influence between reward and recognition on employee engagement. Better awards and recognition will increase the involvement of online motorcycle taxi driver-partners in the city of Batam. The results of this study are in line with the results of research by Sharavan and Arpitha (2015), Taufek, Zulkifle and Sharif (2016), and Osborne and Hammoud (2017).

The level of significance of the relationship between leadership and employee involvement is 0.003 $(<0.05)$. Therefore it can be concluded that there is a significant influence between leadership on employee engagement. Better leadership will increase the involvement of online motorcycle taxi driver-partners in the city of Batam. This study's results are in line with Osborne and Hammoud's (2017) research and Kaliannan and Adjovu's (2015). 
The level of significance of the relationship between employee empowerment and employee involvement is $0,000(<0.05)$. Therefore it can be concluded that there is a significant influence between employee empowerment on employee engagement. Better employee involvement will increase the involvement of online motorcycle taxi driver-partners in the city of Batam. The results of this study are in line with the results of research by Osborne and Hammoud (2017), Taufek, Zulkifli, and Sharif (2016), and Sharavan and Arpitha (2015).

The significance level of the relationship between each independent variable on the dependent variable reveals that each independent variable can partially or separately influence the dependent variable. Appreciation and recognition, leadership, and employee empowerment can partially have a significant effect on employee involvement in online motorcycle taxi driver-partners in the city of Batam. So that if one of the independent variables (such as appreciation and recognition) increases, the dependent variable (employee involvement) will increase. If there is an increase in the leadership variable alone, then employee involvement will also increase. The same thing will also apply if there is an increase in the employee empowerment variable, then employee involvement will also increase.

The results also revealed that rewards and recognition $($ Beta $=0.266)$ and employee empowerment (Beta $=0.262)$ contributed the most to increasing employee engagement. Meanwhile, leadership $($ Beta $=0.194)$ gave the smallest contribution among the three variables used.

The final test results that will be presented by the author in this study are the results of the R Square analysis. The value of Adjusted R Square is 0.383 . These results reveal that the independent variable can only explain the dependent variable by $38.3 \%$. Meanwhile, $61.7 \%$ is explained by other factors that are outside this research model. Several previous studies that examined the factors that influence employee engagement also had an adjusted R2 value between 0.28 and a maximum of 0.70 (Sharma, Goel, and Sengupta, 2017; Camargo, 2016).

\section{Conclusion}

The purpose of this study was to determine whether the variables of appreciation and recognition, employee empowerment, and leadership had a significant positive effect on employee involvement (online motorcycle taxi drivers) in the city of Batam. The study results reveal that appreciation and recognition, employee empowerment, and leadership have a significant favorable influence on online motorcycle taxi driver-partners who are members of the Gojek, Grab, and Maxim applications. Among the three factors that influence online motorcycle taxi driver partners' involvement, appreciation and recognition, and empowerment of employees are the factors that must play a role in increasing employee engagement. Meanwhile, leadership does not play a role in increasing employee engagement.

Online motorcycle taxi driver-partners who feel better appreciation and recognition will show higher engagement with companies (Gojek, Grab, and Maxim). This can be seen through the readiness and readiness of the online motorcycle taxi driver-partners in taking orders that enter through the application. Online motorcycle taxi driver-partners who feel the empowerment of employees from the company that owns the application also show a good and positive attitude by always paying attention to the services provided to their customers (passengers). Likewise, when online motorcycle taxi driver-partners provide servants for food purchases, delivery of goods, and other services. Online motorcycle taxi driver-partners do not feel leadership because all activities carried out have been conveyed through the application so that the figure of a leader who is generally present at every work relationship does not affect the involvement of online motorcycle taxi driver-partners in the company that owns the application.

The research that has been conducted by the author is still far from perfect and has many limitations, which are expected to be further complemented by conducting further research related to employee involvement. The following are the limitations that the authors encountered during the completion of this research and some recommendations that can be made:

1. The author experiences limitations when collecting respondents because many online motorcycle taxi drivers are not operating due to the Covid-19 pandemic. It is recommended that further research be carried out when conditions return to normal after the Covid-19 pandemic has passed.

2. The authors also experience limitations with the adjusted R Square value in the model used by the author. The adjusted $R$ square value of 0.383 is still between the average value and the minimum value of the adjusted R Square reference of the journal used as the author's reference. It is recommended that in the future, you can conduct research using other independent variables so that you can get an adjusted $\mathrm{R}$ square value above the reference average value used by the author.

The results of the research conducted by the author indicate that the independent variables studied have had a significant positive effect on the involvement of online motorcycle taxi driver-partners in the city of Batam. Therefore, several things are suggested for online motorcycle taxi service providers to increase driver involvement as follows:

1. Rewards and recognition are independent variables that have the most considerable contribution than the other two independent variables on employee involvement. Therefore, it is recommended that online motorcycle taxi service providers pay more attention to the appreciation and recognition of online motorcycle taxi driver-partners so that the involvement of online motorcycle taxi driver-partners in the 
company can increase. The increasing involvement of online motorcycle taxi driver-partners with the company, of course, the more profitable the company will be in terms of business development, profits, brand image, etc.

2. Employee empowerment is the variable that provides the second-largest contribution after appreciation and recognition. It is recommended that the company that owns the application increase the empowerment of its employees (online motorcycle taxi driver partners) so that the qualifications of online motorcycle taxi driver partners will increase according to the standards of the company that owns the online motorcycle taxi application. This is important because the qualifications of an excellent online motorcycle taxi driver partner (according to company standards) will affect the company's brand image. With a right brand image, the company will get more and more trust from customers, which will affect the sustainability of the company itself in the online transportation business world.

3. Leadership has the smallest contribution to employee engagement. It is recommended for companies that own online motorcycle taxi applications to increase their leadership role for their online motorcycle taxi driver-partners. Online motorcycle taxi driver partners can still feel a positive relationship with the company's leadership and feel direct involvement with the company through the leadership applied by the online motorcycle taxi provider company.

\section{References}

Adiyanta, F. C. S. (2019). Hukum dan Studi Penelitian Empiris: Penggunaan Metode Survey sebagai Instrumen Penelitian Hukum Empiris. Adminitrative Law \& Governance Journal., 2(4), 697-709.

Agustin, I. N. (2017). Modul Laboratorium Statistika Program Studi Manajemen Aplikasi Software Spss dan Smart PLS (I. N. Agustin (ed.)). Laboratorium Statistika Program Studi Manajemen Fakultas Ekonomi Universitas Internasional Batam.

Baumruk, R., Gorman, Jr., B., \& Gorman, R. E. (2006). Why managers are crucial to increasing engagement. Strategic HR Review, 5(2), 24-7.

Bhavani, Sharavan, \& Arpitha. (2015). Kaav International Journal of Economics. 4(10), 7. https://doi.org/10.4172/21626359.1000295

Breevaart, K., Bakker, A., Hetland, J., Demerouti, E., Olsen, O. K., \& Espevik, R. (2014). Daily transactional and transformational leadership and daily employee engagement. Journal of Occupational and Organizational Psychology, 87(1), 138-157.

https://doi.org/10.1111/joop.12041

Brown, D., \& Reilly, P. (2013). Reward and Engagement. Compensation \& Benefits Review, 45(3), 145157. https://doi.org/10.1177/0886368713497546

Burton, W. N., Chen, C. Y., Li, X., \& Schultz, A. B. (2017). The Association of Employee Engagement at Work with Health Risks and Presenteeism. Journal of Occupational and Environmental Medicine, 59(10), 988-992. https://doi.org/10.1097/JOM.0000000000001108

Cahyu. (2019). Kisah Perjalanan Grab Dari Lahir Hingga Jadi Decacorn. https://www.liputan6.com/tekno/read/3912922/kisah-perjalanan-grab-dari-lahir-hingga-jadi-decacorn

Gaëtane Caesens, F. S. and G. L. (2014). 기사 (Article) 와 안내문 (Information) [. The Impact of Work Engagement and Workaholism on Well-Being The Role of Work-Related Social Support, 34(1), 813835.

Gojek. (2018). Kini GO-JEK Hadir di 167 Kota dan Kabupaten Indonesia. https://www.gojek.com/blog/gojek/go-jek-dimana-mana/

Grab. (2020). No Title. https://www.grab.com/id/locations/

Green, P. I., Finkel, E. J., Fitzsimons, G. M., \& Gino, F. (2017). The energizing nature of work engagement: Toward a new need-based theory of work motivation. Research in Organizational Behavior, 37, 1-18. https://doi.org/10.1016/j.riob.2017.10.007

Hanaysha, J. (2016). Examining the Effects of Employee Empowerment, Teamwork, and Employee Training on Organizational Commitment. Procedia - Social and Behavioral Sciences, 229, 298-306. https://doi.org/10.1016/j.sbspro.2016.07.140

Ho, E., Clarke, A., \& Dougherty, I. (2015). Youth-led social change: Topics, engagement types, organizational types, strategies, and impacts. Futures, 67, 52-62. https://doi.org/10.1016/j.futures.2015.01.006

Hughes, J. C., \& Rog, E. (2008). Talent management: A strategy for improving employee recruitment, retention, and engagement within hospitality organizations. International Journal of Contemporary Hospitality Management, 20(7), 743-757. https://doi.org/10.1108/09596110810899086

Ikhsan, M. (2019). Kenalan Dengan Maxim, Aplikasi Transportasi Online Baru di Batam. https://www.batamnews.co.id/berita-52322-kenalan-dengan-maxim-aplikasi-transportasi-online-baru-dibatam.html

Kahn, W. A. (1990). Psychological conditions of personal engagement and disengagement at work. Academy of Management Journal, 33(4), 692-724. 
Kaliannan, M., \& Adjovu, S. N. (2015). Effective Employee Engagement and Organizational Success: A Case Study. Procedia - Social and Behavioral Sciences, 172, 161-168. https://doi.org/10.1016/j.sbspro.2015.01.350

Keyko, K., Cummings, G. G., Yonge, O., \& Wong, C. A. (2016). Work engagement in professional nursing practice: A systematic review. International Journal of Nursing Studies, 61, 142-164. https://doi.org/10.1016/j.ijnurstu.2016.06.003

Kumparan. (2020). Organisasi Ojol: Ada 4 Juta Driver Ojol di Indonesia. https://kumparan.com/kumparantech/organisasi-ojol-ada-4-juta-driver-ojol-di-indonesia1tBrZLEXOEI/full

Maciel, C. de O., \& Camargo, C. (2016). Social connection in organizations: the effects of local ties on job engagement and performance. Revista de Administração, 51(4), 377-385. https://doi.org/10.1016/j.rausp.2016.07.005

Markos, S., \& Sridevi, M. S. (2010). Employee engagement: The key to improving performance. International Journal of Business and Management, 5(12), 89.

Mone, E., Eisinger, C., Guggenheim, K., Price, B., \& Stine, C. (2011). Performance Management at the Wheel: Driving Employee Engagement in Organizations. Journal of Business and Psychology, 26(2), 205-212. https://doi.org/10.1007/s10869-011-9222-9

Osborne, S., \& Hammoud, M. S. (2017). Effective Employee Engagement in the Workplace. International Journal of Applied Management and Technology, 16(1), 50-67. https://doi.org/10.5590/ijamt.2017.16.1.04

Pan, X., Mao, T., Zhang, J., Wang, J., \& Su, P. (2017). Psychological capital mediates the association between nurses' practice environment and work engagement among Chinese male nurses. International Journal of Nursing Sciences, 4(4), 378-383. https://doi.org/10.1016/j.ijnss.2017.09.009

Parent, J. D., \& Lovelace, K. J. (2015). The Impact of Employee Engagement and a Positive Organizational Culture on an Individual's Ability to Adapt to Organization Change. Eastern Academy of Management Proceedings: Organization Behavior and Theory Track, 1-20. http://scholarworks.merrimack.edu/mgt_facpubhttp://scholarworks.merrimack.edu/mgt_facpub/10

Perrin, T. (2003). Working Today: Understanding What Drives Employee Engagement. The 2003 Towers Perrin Talent Report, 1-34.

Raziq, A., \& Maulabakhsh, R. (2015). Impact of Working Environment on Job Satisfaction. Procedia Economics and Finance, 23(October 2014), 717-725. https://doi.org/10.1016/s2212-5671(15)00524-9

Robinson, D., Perryman, S., \& Hayday, S. (2004). The drivers of employee engagement. Report-Institute for Employment Studies.

Salmela-Aro, K., \& Upadyaya, K. (2018). Role of demands-resources in work engagement and burnout in different career stages. Journal of Vocational Behavior, 108, 190-200. https://doi.org/10.1016/j.jvb.2018.08.002

Schaufeli, W. B., \& Bakker, A. B. (2004). Job demands, job resources, and their relationship with burnout and engagement: A multi-sample study. Journal of Organizational Behavior: The International Journal of Industrial, Occupational and Organizational Psychology and Behavior, 25(3), 293-315.

Sharma, A., Goel, A., \& Sengupta, S. (2017). How does Work Engagement vary with Employee Demography?: - Revelations from the Indian IT industry. Procedia Computer Science, 122, 146-153. https://doi.org/10.1016/j.procs.2017.11.353

Sonnentag, S. (2017). A task-level perspective on work engagement: A new approach that helps differentiate the concepts of engagement and burnout. Burnout Research, 5(October 2016), 12-20. https://doi.org/10.1016/j.burn.2017.04.001

Spawr, A. L. (2012). Journal of Community \& Applied Social Psychology. Journal of Community \& Applied Social Psychology: Book Review, 92-94. https://doi.org/10.1002/casp

Sujarweni, V. W. (2014). Metodologi Penelitian (V. Wiratna Sujarweni (ed.); I). Pustaka Baru Press.

Taufek, F. H. B. M., Zulkifle, Z. B., \& Sharif, M. Z. B. M. (2016). Sustainability in Employment: Reward System and Work Engagement. Procedia Economics and Finance, 35(October 2015), 699-704. https://doi.org/10.1016/s2212-5671(16)00087-3

Thomas, M., Pidgeon, N., \& Bradshaw, M. (2018). Shale development in the US and Canada: A review of engagement practice. Extractive Industries and Society, 5(4), 557-569. https://doi.org/10.1016/j.exis.2018.07.011

Vallières, F., McAuliffe, E., Hyland, P., Galligan, M., \& Ghee, A. (2017). La medición del compromiso con el Trabajo en Trabajadores sanitarios comunitarios de Sierra Leona: validación de la Escala Utrecht de Engagement. Revista de Psicologia Del 